\title{
Developing an Interactive Mathematics Multimedia Learning Based on Ispring Presenter in Increasing Students' Interest in Learning Mathematics
}

\author{
M. Saidun Anwar ${ }^{1}$, Choirudin ${ }^{2}$, Eka Fitria Ningsih ${ }^{3}$, Triana Dewi ${ }^{4}$, Andino Maseleno ${ }^{5}$ \\ 1,2,3,4 Institut Agama Islam Ma'arif NU (AIMNU) Metro Lampung, Indonesia \\ ${ }^{5}$ Institute of Information and Computing in Energy, University Tenaga Nasional, Malaysia \\ ${ }^{2}$ Correspondence Address; choirudiniaimnumetro@gmail.com
}

\begin{abstract}
The purpose of this study is to develop a multimedia learning based on iSpring Presenter to increase students' interest in learning in mathematics. This study uses the ADDIE development model which consists of five stages, namely analysis, design, development, implementation, and evaluation. The data analysis technique used is descriptive quantitative. The results showed that the interactive mathematics multimedia learning based on iSpring Presenter has fulfilled the requirements to be considered feasible to be used in the learning process and is feasible to be used as learning support media to increase students' interest in learning through varied learning activities.
\end{abstract}

Keywords: iSpring Presenter, Interactive Mathematics Multimedia, Interest in Learning Mathematics.

\section{INTRODUCTION}

The teachers are the central point in the implementation of learning because they are one of the components of education that deal directly with students. Teachers are an important component in achieving learning objectives in order to improve the quality of education, but in this effort, there are certainly many things that become obstacles for them. One of the obstacles encountered is growing students' interest in learning. The interest in learning is a very important influence on the success of learning, especially in mathematics learning. Students' interest is one of the internal factors that influence students' learning achievement known as conditions or situations related to individual desires or needs (Yeh, Cheng, Chen, Liao, \& Chan, 2019) Interest is always related to wants or needs. It is important to create conditions so that the students always need and want to learn. In relation to learning mathematics, interest is something important. A person with high interest will have high motivation. A high learning interest will make the students' have positive attitudes towards mathematics (Azmidar, Darhim, \& Dahlan, 2017; Yeh et al., 2019)

The students' Interest in learning can be caused by the learning media used by the teacher. Many schools have facilities and infrastructure that are quite complete and well-classified. One of which is the existence of a computer laboratory room and the availability of LCD projectors. Unfortunately, the complete facilities and infrastructure are not optimally utilized by the teacher to support the learning process. The teacher states that the mathematics learning pattern used is still conventional. The teacher is only guided by textbooks and only writes on the board without using other learning media. This is because the teacher lacks sufficient ability to make innovative learning media and a limited amount of time in creating interactive learning media(Subandi, Choirudin, Mahmudi, Nizaruddin, \& Hermanita, 2018). Therefore, efforts to develop learning media are important to do.

There are many media to support and improve the quality of mathematics learning, one 
of which is iSpring. iSpring presents application software that can help teachers explain the subject matter. Furthermore, this software converts a powerpoint presentation into flash format. iSpring also provides learning material in slides that contain images, animations, videos, and audio to be more interesting, practical, and ideal. This has a positive impact on the learning process (Cahyanti, Farida, \& Rakhmawati, 2019; Nurwijayanti, Budiyono, \& Fitriana, 2019)

Several studies have been carried out to develop learning tools to help facilitate the learning process (Andari \& Lusiana, 2014; Asmawati \& Wuryanto, 2014; Febriana, Sulur, \& Yudyanto, 2014; A. Fitri, 2011; Hartono \& Noto, 2017; Indraningtias, Diah, \& Ariyadi Wijaya, 2017; Melisa, 2016; Nisak, 2013; Rizkiah, Nasir, \& Komarudin, 2018; Rudiono, Dafik, \& Wahyuningrum, 2015; A. U. Sari, Farida, \& Putra, 2017; F. K. Sari, Farida, \& Syazali, 2016; Sulistyowati \& Sugiman, 2014; Supiyati \& Jailani, 2014; Supriadi, Farida, \& Lestari, 2018; Susanti, Musdi, \& Syarifuddin, 2017; Wijayanti \& Sungkono, 2017; Yusnita \& Subanti, 2014) . As well as research on developing learning media based on iSpring (Afandi, 2017; Cahyanti et al., 2019; Himmah, 2017; Nurwijayanti et al., 2019; Sastrakusumah, 2018; Vikulova, Makarova, \& Gerasimova, 2018; Wagino \& Zaenuddin, 2015) And research with the aim of increasing students' interest (Aprilia, 2012; H. Fitri \& Wardi, 2026; Harsyad, Afif, \& Abrar, 2016; Kinta Marini \& Hamida, 2014; Siagian, R.E.F., 2015) However, no previous research has developed interactive mathematics multimedia learning based on iSpring Presenter to increase students' learning interest.

Based on the research that has been done before, the renewal in this study lies in the development of an interactive mathematics multimedia learning based on iSpring Presenter increase students' learning interest in Trigonometry material. So, the purpose of this study is to develop an interactive mathematics multimedia learning based on iSpring Presenter to increase students' learning interest in mathematics.

\section{THE RESEARCH METHODS}

The research method used in this study is research and development ( $\&$ \& $)$ which refers to the ADDIE model (Analysis of Design Development Implementation and Evaluation) (Sugiyono, 2015). The model consists of 5 stages, namely (1) Need analysis; (2) Design; (3) Development; (4) Implementation; (5) Evaluation.(Choirudin, 2017). The model is presented in Figure 1.

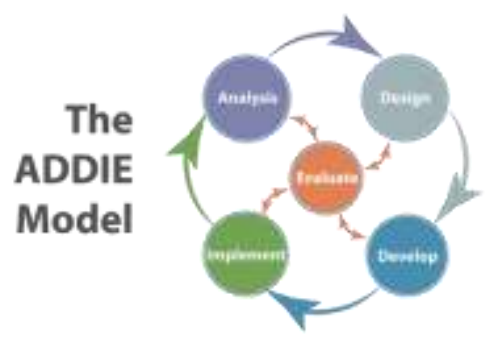

Figure 1. ADDIE Development Model

The data collecting techniques used are observation, questionnaire, and documentation. The data analysis technique used is quantitative descriptive data analysis techniques (Nazir, 
2010). The data of the quantitative descriptive analysis is obtained from the questionnaire in the form of descriptive which then quantified to get results in the form of numbers. The percentages are used to find out the results of the questionnaire from the validation of media experts, material experts, and respondents (Sugiyono, 2011).

Table 1. Qualitative Percentage Range Criteria

\begin{tabular}{ll}
\multicolumn{1}{c}{ Interval } & Criteria \\
\hline $81,25 \%>$ Score $\leq 100 \%$ & Excellent \\
$62,50 \%>$ Score $\leq 81,25 \%$ & Good \\
$43,75 \%>$ Score $\leq 62,50 \%$ & Moderate \\
$25 \% \geq$ Score $\leq 43,75 \%$ & Poor
\end{tabular}

Table 1 shows the percentage range value as a reference for evaluating the results of the experts' validation. To see an increase in students' interest in learning before and after being given treatment, the researchers used the $\mathrm{N}$-gain test.

Table 2. N-Gain Value Criteria

\begin{tabular}{ll}
\hline Interval & Criteria \\
\hline $\mathrm{g}>0,7$ & High \\
$0,3 \leq \mathrm{g} \leq 0,7$ & Moderate \\
$\mathrm{g}<0,3$ & Low \\
\hline
\end{tabular}

Table 2 describes the $\mathrm{N}$-Gain value criteria for the interest in mathematics learning while using iSpring Presenter media.

\section{THE RESULTS OF THE RESEARCH AND THE DISCUSSION}

This research was conducted using the Research and Development ( $R$ \& D) approach with the ADDIE development model. The model consists of five stages, namely analysis, design, development, implementation, and evaluation. Therefore, the researcher will describe the results of the development of learning media according to the ADDIE stages.

\section{Analysis}

The analysis is the first step that must be done before compiling a program or media in learning because, at this stage, the problems found in learning are examined to find out how to solve them.

First, the results of observations by the researchers indicate that the students' learning interest is quite low. This can be seen based on questionnaires and observations in the classroom where most students claim to be bored and often sleepy when the learning process takes place. Students claim that conventional teaching methods do not make them interested in learning and make them prefer to sleep in class. Another thing that causes low interest in learning is that the teacher teaches in a voice that is not clear enough and writes too much on the board. Learning mathematics, according to the students, is quite difficult and boring because, during learning, they are required to master much material, understand mathematical formulas, and just sit in class because the teacher does not provide other media besides student worksheet. The teacher does not have enough ability and time to provide other learning media so students are only 
provided with student worksheets and notes in the hope that students will study at home, even though according to the students, they only learn when approaching tests or exams.

\section{Design}

The design phase is the preparation stage for creating learning media by compiling competency maps, material maps, outlines of media content, flowcharts, and media content. Competency map is a chart or plot that explains several indicators that must be mastered by students in Trigonometry material. The competency maps are made based on mathematics syllabus.

The material map is a chart or plot which is a breakdown of some Trigonometry material. The material map is adjusted to the subject matter contained in the student book. Outline of media content is a guide in writing a script. It contains the main points of Trigonometry material which are then designed into a media made using powerpoint and are then integrated into the iSpring Presenter. The outline of media content refers to the syllabus used by the teacher. A flowchart is a type of diagram that represents an algorithm, workflow, or process which displays steps in the form of graphic symbols and sequences conjoined by an arrow. The purpose of making a flowchart is to describe the stages of operation of product development. The media content is a guideline for making interactive mathematics multimedia learning using ISpring Presenter. Media content consists of display information, animated captions, video captions and audio information (backsound). The development process is started in the PowerPoint slides that comprises by making an introduction, determining the background and navigation, creating a home menu, making a material menu, and making practice questions.

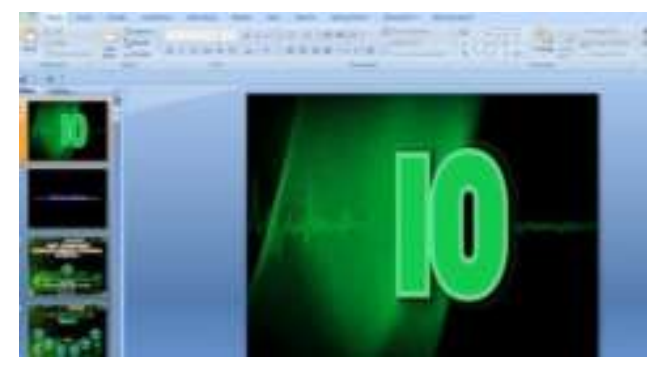

Figure 2. Opening

Figure 2 describes the opening on the Powerpoint slide is the form of the video within a 10 seconds duration.

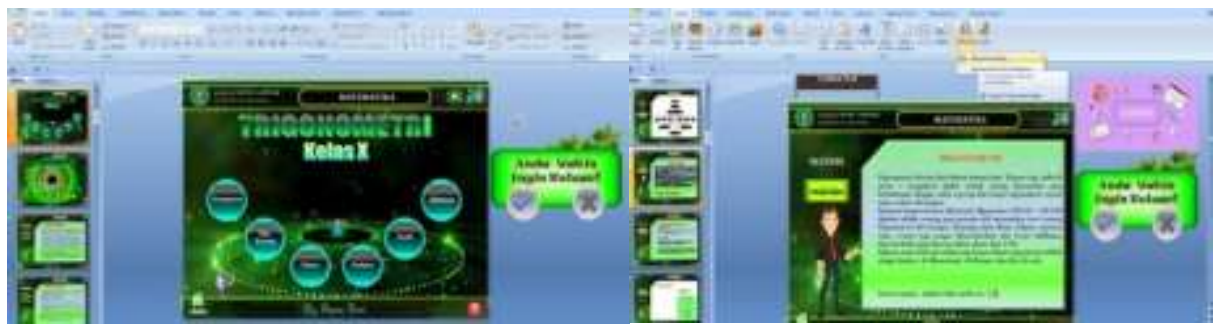

Figure 3.Home Menu and Insert Video 
Figure 3 describes the video on the screen that has been edited using VideoPad, then inserted into a Powerpoint slide.

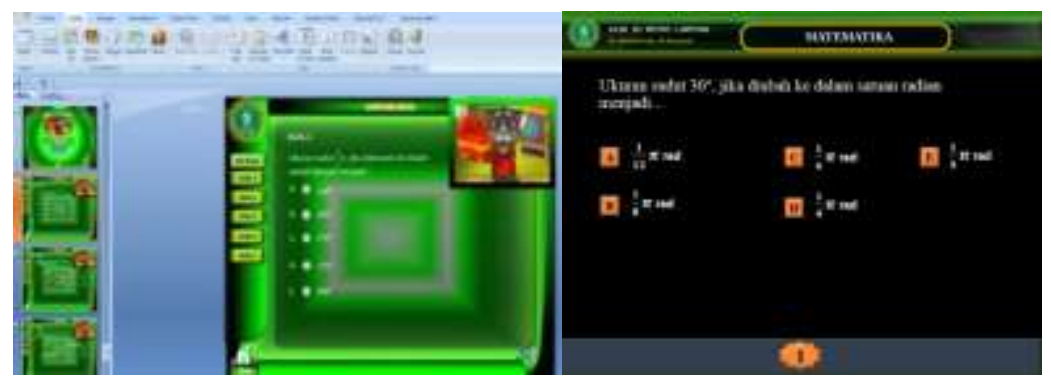

Figure 4. Making Practice Questions

Figure 4 describes the display of exercises and evaluation questions. There are animated cats that can produce notification sound when the students answer right or wrong so students will later find out their answers. The last part is to convert the Powerpoint into SWF format.

\section{Development}

This stage is the stage of media production where media creation is tailored to the text that has been designed. In this stage, the finished media is examined and validated by media experts and material experts so that it can be used in learning. The production process of interactive mathematics multimedia learning using iSpring Presenter consists of three stages, namely the pre-production stage, the production stage, and the post-production stage.

The pre-production stage begins with the preparation of all the tools needed to make the learning media, both hardware, and software. The hardware consists of a laptop and a mouse while the software consists of the iSpring Presenter and also some supporting software so that the media can be packaged as needed, namely Microsoft Office PowerPoint as a graphic design processor, VideoPad as a video \& audio processor, and PhotoScape as an image processor.

The production stage begins by making the product according to the media script that has been made. The steps in the production process are as follows:

a. After all the necessary applications have been installed, then the contents are loaded into the product. The content is in the form of narration, animation, images, audio, and video.

b. After the content in the product is ready, the layout of the product is designed by making the opening and setting the background color. the Powerpoint application is used in making this product.

c. After the opening and background are finished, the font size, type, and color are adjusted.

d. creating animation.

e. Creating and loading the content into Powerpoint.

f. Once the process has been finished, the product is then converted into SWF format.

The post-production stage is the activity of reviewing and evaluating the media that has been produced. At this stage, the media is made and published in the production stage and then the product is examined in its entirety. This stage investigates whether the volume is appropriate, does the navigation button have the correct function, whether the text is appropriate, whether the image is correct in terms of size and resolution, and whether the animation is good in terms of size and resolution. If some points are still not good, they will be corrected but if the points are generally good, then the product is ready for the next stage. 
The main activity in the post-production is the validation of the product. The validators consist of media experts and material experts. The media must pass the validation stage because, at this stage, the media will be reviewed by the validators and corrected by the researcher so that the media is considered feasible to be used in learning. The following are the results of validation by media experts.

Table 3. Results of Media Expert Validation

\begin{tabular}{lcccc}
\multicolumn{1}{c}{ Aspects assessed } & Value & Max Value & Percentage & Desc. \\
\hline Display & 46 & 64 & $71.87 \%$ & Good \\
Programming & 23 & 24 & $95.83 \%$ & Ex \\
Total Assessment & 69 & 88 & $78.41 \%$ & Good \\
\hline
\end{tabular}

From Table 3, it can be described that the data from the validation assessment of media experts obtain a percentage of $71.87 \%$, programming gets a percentage of $95.83 \%$, and the total assessment obtains a percentage of $78.41 \%$.

The data obtained are of two kinds, namely qualitative and quantitative data. Qualitative data in the form of criticism/suggestions and input while the quantitative data is obtained from the questionnaire assessment. The results of the expert assessment of the material aspects can be seen in the following table.

Table. 4 Material Expert Validation

\begin{tabular}{ccccc}
\hline Aspects assessed & Value of & Max Value & Percentage & Desc. \\
\hline Content & 21 & 24 & $87.5 \%$ & Excellent \\
Learning & 48 & 64 & $75 \%$ & Good \\
Total Assessment & 69 & 88 & $78.41 \%$ & Good \\
\hline
\end{tabular}

Based on table 4, Data can be described that the validation assessment results from the material experts indicate that the content aspect obtains a percentage $87.5 \%$, learning aspect obtains a percentage of $75 \%$, and the total assessment obtains a percentage of $78.41 \%$,

This media is feasible to be tested in the field with revisions according to the advice of the validators. The validators provide several suggestions for improving the media, as follows. 1) The type of writing and font on the material menu is not large enough so that it is difficult to read and does not match the display proportions because there are still many empty places available. The color of the text also doesn't match the display so the text doesn't look clear and is hard to read.

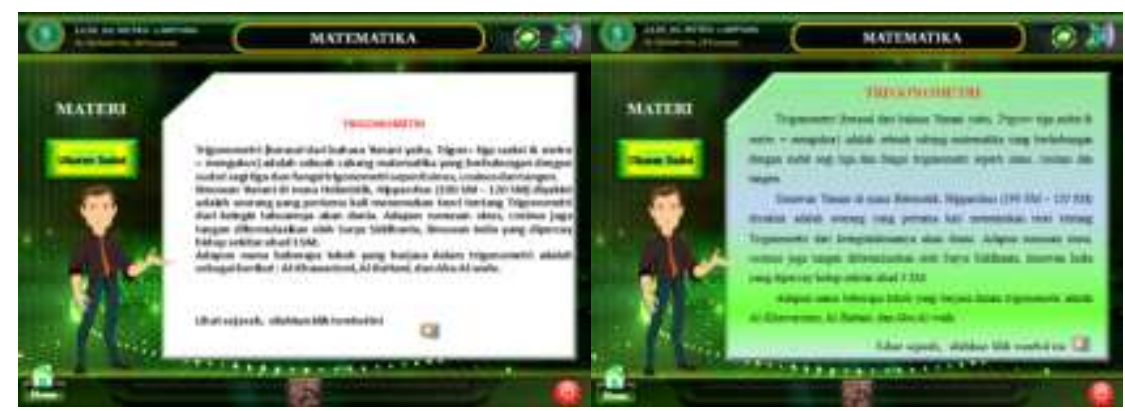

Figure 5. Display of Menu Material Before and After Revision 
Figure 5 describes the display of menus developed in the material before and after the revision process.

2) Animation questions and answer choices on practice questions appear one by one. This causes students to wait to be able to read the questions in full. It's best to make animated questions and answer choices appear together just to save time and be more readable. The animation for the correct and incorrect answers is less interesting since it is only in the image format. It is better to change the animation and provide audio to the animation to make it more attractive. The results of the revision are animated questions and answer choices appear at once and the animation of the correct and incorrect answers is changed by adding audio to the animation so that it is more interesting.

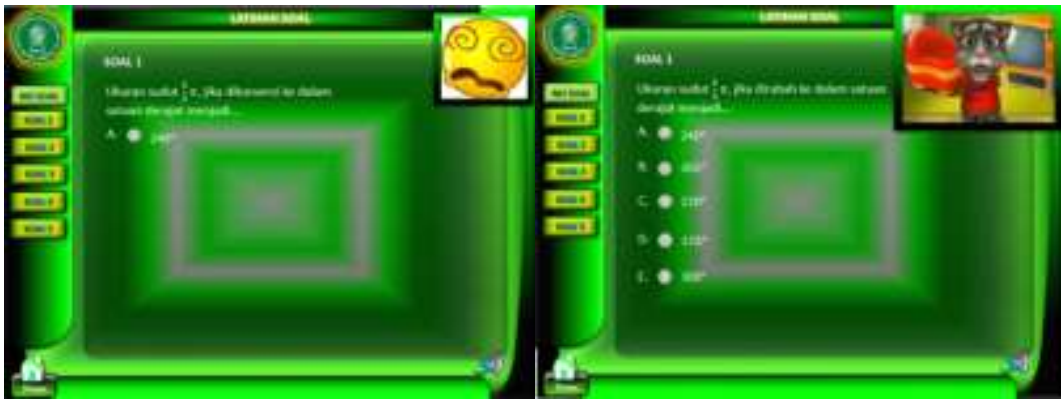

Figure 6. Display of Practice Questions Before and After Revision

Figure 6 describes the display of exercises before and after the revision process.

3) The display quality of the pictures on the evaluation question is low so the image does not seem very clear. Use high-quality pictures so that it appears clear. The result of the revision is that the picture is clear because the image has been replaced with a high-quality one. Display image after revision.

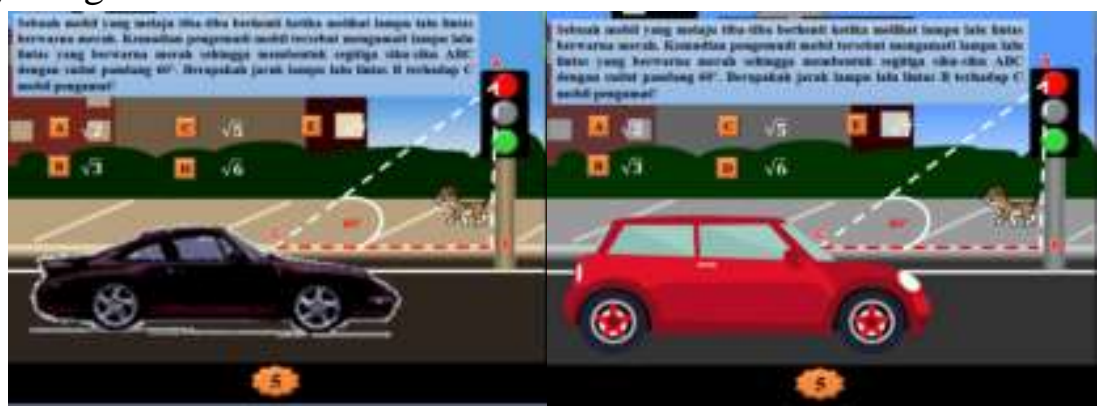

Figure 7. Display of Evaluation Questions Before and After Revision

Figure 7 describes the evaluation questions developed in the material before and after the revision process.

4) Backsound is not relevant to the contents of the material. It is recommended to use a backsound that is appropriate and can support the ongoing learning activities in the classroom. 


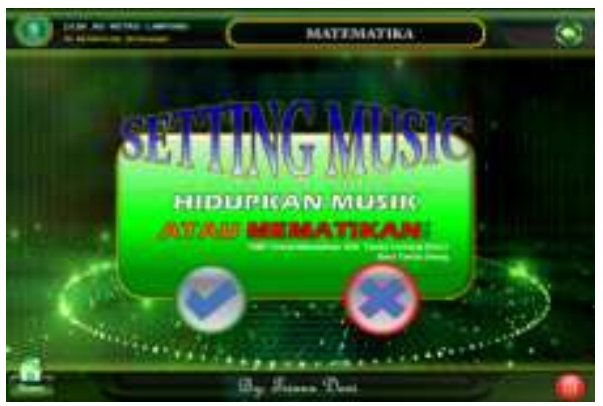

Figure 8. Display of Backsound After Revision

Figure 8 describes the backsound used is originally mellow. After being revised, the backsound is changed into a moderate rhythm and was energetic. This media is feasible for further testing in the field with revisions according to the advice of the validators. The validators give some suggestions for improving the material, namely:

5) The example of the Trigonometry Comparison problem, especially in the solution part, is less clear and too short. It is better to clarify the completion of the example with the explanation "Known" and "Asked" so that later, the students are not confused in understanding the example problem. Display of sample questions can be seen. The result of the revision is that the completion of the sample questions is clarified and emphasized with the words "Known" and "Asked". Answers will appear and remain in one view if the button 10 is clicked.

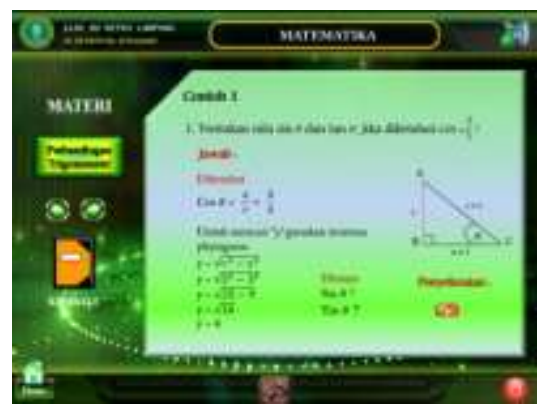

Figure 9. Display of Problem Samples and Completion of Trigonometry Comparison After Revision

Figure 9 describes examples of questions and menu resolutions developed in the material after the revision process.

6) In the example of the Angular Relation problem, the question should not only ask for the operation but must involve several calculation operations, such as addition, division, and multiplication. Display of the example of a function relation problem is as follows. The results of the revision are the questions is added the features of multiplication and divisions operations. So that is one problem, there are three solutions that must be done. Objectives are made like this so that the students understand more about various calculation operations. 


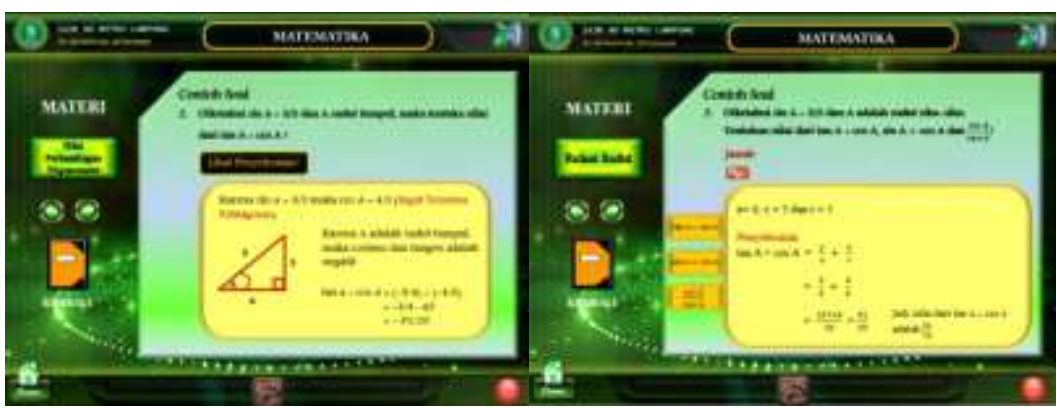

Figure 10. Display of Examples Before and After Revision

Figure 10 describes the appearance of examples developed in the material before and after the revision.

7) Eliminate the explanation of the general form information on the material in each graph of the Trigonometry function. Include a table before making a graph so the students know the basics of making a graph based on the table. Display graph material functions. The result of the revision is that the material has been changed, the general form of the Trigonometric function is omitted, and tables are added in the material.

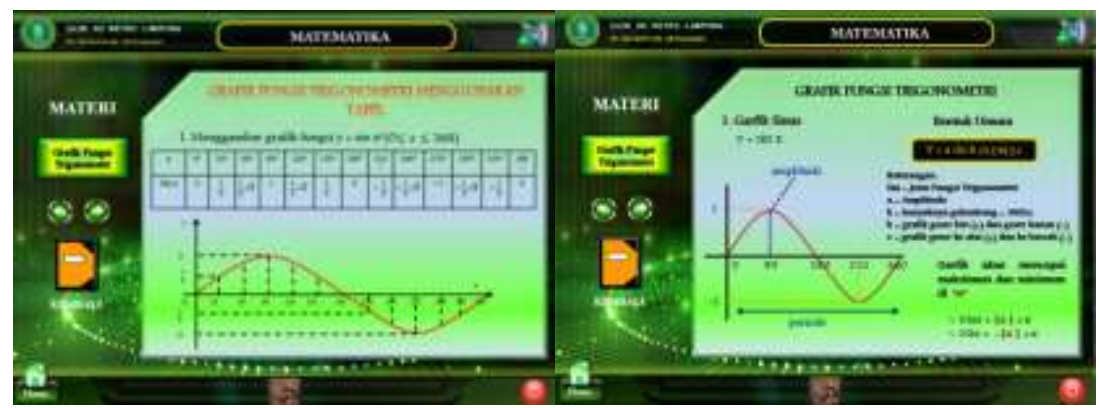

Figure 11. Display of Graphs of Trigonometric Functions After Revision

Figure 11 describes the graphical display developed in the material after the revision process.

\section{Implementation}

The implementation stage is where the media that has been produced is used in learning. The interactive mathematics multimedia learning based on iSpring Presentation was applied to the tenth-grade students of MA (Islamic Senior High School) Tri Bhakti At-taqwa Raman Utara, East Lampung Regency.

In the first meeting, the researchers used interactive mathematics multimedia learning based on iSpring Presentation as a tool in explaining the concept of Trigonometry material. This is done so that students know the description of the material to be studied. At the first meeting also, the researcher used this medium as a tool to explain the material of angular size, Trigonometry comparison, and Trigonometry comparison value at 00, 300, 450, 600 and 900. In the second meeting, the researchers used the interactive mathematics multimedia learning based on iSpring Presentation as a tool in explaining angular relations and graphs of Trigonometry functions.

\section{Evaluation}

The final stage of this development is to evaluate the media that has been implemented. The evaluation is intended to clarify the use of media in increasing students' learning interest 
in Trigonometry material. To know the improvement of students' learning interest, a questionnaire was given. The questionnaire was given in two treatments, namely before using the media and after using the media (pretest and posttest).

The questionnaire for learning interest was given to 33 tenth-grade students of MA (Islamic Senior High School) Tri Bhakti At-taqwa Raman Utara, East Lampung Regency. The questionnaire was given to the students in order to find out the description of before and after the product implementation. N-gain test is used to find out the students' interest improvement after the product implementation. The following are the results of measurements of students' learning interest improvement.

Table 5. Results of Measurement on Student Learning Interests

\begin{tabular}{llll}
\hline \multicolumn{1}{c}{ Treatment } & Value & N-Gain & Conclusion \\
\hline The average of pretest & 62.74 & & \\
The average of the posttest & 88.93 & 0.704 & High \\
Maximum score & 112 & & \\
\hline
\end{tabular}

Table 5 shows the average score of students' interest before learning using the developed product is 62.74 and after using the developed product, it changes into 88.93.

Based on the $\mathrm{N}$-gain results, the increase in students' interest is 0.704 . If it is included in the criteria for the N-gain factor, the value is high. This shows that the increase in students' interest in learning after using the developed product is high.

The interest in learning is divided into several indicators, namely interest in learning, attention in learning, learning motivation, and knowledge. The results of measurements perindicator can be seen in the following table:

Table 6. Measurement of Interests

\begin{tabular}{cccccc}
\hline Per-Indicators & pretest & posttest & Max Value & N-Gain & Categories \\
\hline Affinity & 17.39 & 25.39 & 28 & 0.763 & High \\
Attention & 16.91 & 24.73 & 28 & 0.707 & High \\
Motivation & 16.27 & 24.21 & 28 & 0.671 & Medium \\
Knowledge & 19.85 & 25.48 & 28 & 0.699 & Medium \\
\hline
\end{tabular}

Based on the results of data analysis in Table 6, it can be described that the interest is in the high and medium categories. Based on the observations made by researchers during the learning process, the students pay attention to the learning presented by the teacher because they feel interested in the material presented in the form of flash containing text, images, audio, video, and animation. Students also pay more attention to learning such as asking questions when the teacher explains the material. Students are encouraged in the process of learning mathematics in class. Thus, it can be said that students have a fairly high learning interest in learning using interactive multimedia (Subandi et al., 2018).

The interactive mathematics multimedia learning based on iSpring Presenter is a tool that converts presentation files into flash (SWF format) and SCORM / AICC, which are forms commonly used in LMS (Learning Management System) of e-learning (Wagino \& Zaenuddin, 
2015). The iSpring Presenter can be easily integrated with the Microsoft Powerpoint. Actually, Microsoft Powerpoint can be used without using the iSpring Presenter, but the results displayed are less attractive and not optimal. The combination of Microsoft PowerPoint and iSpring Presenter will produce interesting mathematics learning media. Media results from the iSpring Presenter contain images, animations, audio, video, presentations, and other things that require the availability of means of interactions. It is expected through the existence of these advantages the teaching and learning process will be more interesting so that students are interested and comfortable during the learning. The interactive mathematics multimedia learning based on iSpring Presenter is expected to be able to support existing facilities to make it easier for students to master the subject matter and can be used as alternative media that makes it easy to understand abstract to concrete material.

Multimedia is a combination of various media (file format) in the form of text, images (vector or bitmap), graphics, sound, animated video interaction, and others that have been packaged into digital files (computerized) used to convey messages to the public. While interactive understanding is related to the combination of two directions or more of the communication components(Subandi et al., 2018). The component of communication in interactive multimedia is the relationship between humans (as users/ users of products) and computers (software/applications/products in certain file formats, usually on CDs). Thus, t0he product/CD/application is expected to have a two-way reciprocal relationship between software/application and the users. Interactivity in multimedia includes: (1) users are involved to interact with the application program; (2) interactive information application so that users can get only the information they want without having to absorb everything.

Interactive multimedia is a multimedia application that is used in the learning process, in other words, to channel the messages (knowledge, skills, and attitudes) and can stimulate thoughts, feelings, attention, and willingness to learn so that the learning process deliberately occurs and the aims are controlled (Sastrakusumah, 2018). Interactive multimedia as a unique form that involves information. This multimedia component is characterized by the presence of text, images, sound, animation, and video. The interactive components refer to the process of empowering users to control the environment, usually with computers.

Green \& Brown explain that there are several methods used in presenting multimedia, namely: 1) Based on paper (paper-based), for example books, magazines, brochures; 2) Based on the light (light-based), for example slide shows, transparency; 3) Sound (audio-based), for example, CD player, tape recorder, radio; 4) Based on moving images (moving-image-based), for example, a television, VCR (video cassette recorder), film; 5) Digital based (digitallybased), example: computer (Munir, 2015) 


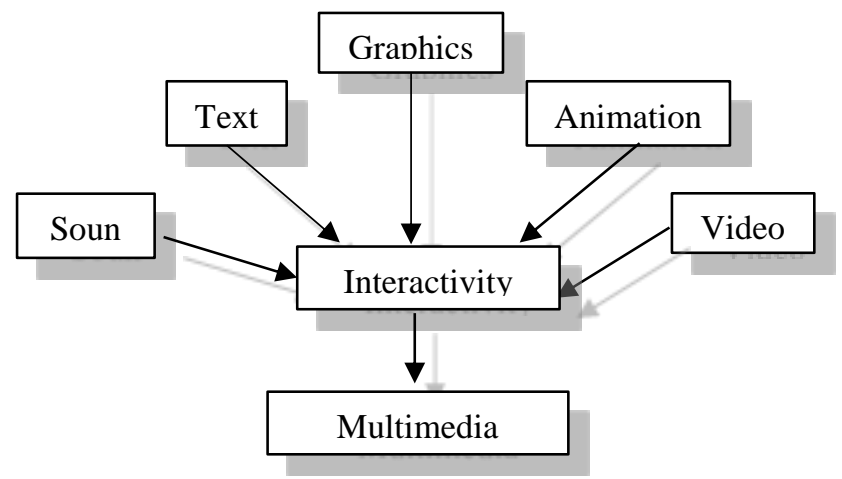

Figure 12. Interactivity as a Multimedia Application Center

Figure 12 illustrates that interactivity is a combination of various media: sound, text, graphics, animation, and video presented in a multimedia application. The presence of interactivity and interactive features in multimedia applications has bridged the interaction between the computer and the users. The key to interactivity is the empowerment of users in using multimedia applications so that they can control the content and flow of information. This has stimulated important changes in the education system and the impact of how information is delivered to the students. The advancement of multimedia technology helps the development of the ability to effectively utilize interactive multimedia in the learning process.

iSpring is a software designed to make flash e-learning content from presentations into a flash format that is ready for use. In other words, iSpring is one tool that converts presentation files into flash forms and CORM / AICC forms, which are forms commonly used in LMS (Learning Management System) e-learning. iSpring Presenter can be easily integrated into Microsoft Powerpoint so that its use does not require complex expertise. As for some of the primacy of iSpring Presenter application in supporting students' interest, namely: 1) iSpring Presenter works as a PowerPoint add-ons to make PowerPoint file more attractive and interactive and can be opened on almost any computer or platform; 2) iSpring Presenter is developed to support e-learning which can also insert various forms of media so that the resulting learning media will be more interesting including being able to record and synchronize video presenters, add flash and YouTube videos, import or record audio, add presentation maker information and company logos, and create unique navigation and designs; 3) Easy to distribute in flash format, can be used anywhere, and is optimized for the web; 4) Make a quiz with various types of questions, namely: true/false, multiple choice, multiple response, type in, matching, sequence, numeric, fill in the blank, multiple choice text

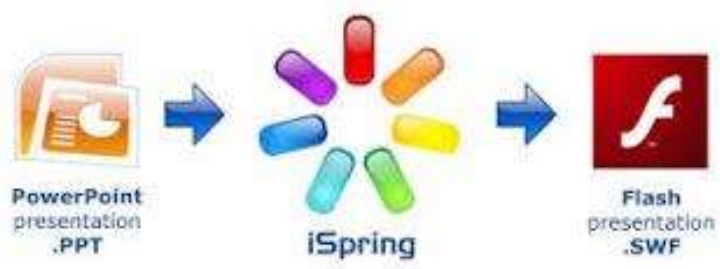

Figure 13. iSpring Presenter 
From Figure 13, it can be described that iSpring Presenter has a display feature that works as a Powerpoint add-ons, to make Powerpoint files more interesting and interactive based on flash format and can be opened on almost every computer or platform. The iSpring itself is developed to support e-learning so it supports various menus and to insert media forms. So that the learning media produced will be more interesting.(Vikulova et al., 2018)

The interactive mathematics multimedia learning based on iSpring Presenter on the tenthgrade Trigonometry material is successfully developed media because it is developed according to the design and able to provide assistance in learning, especially to increase students' learning interest. This is in accordance with previous research conducted by Arlitya which explains that the iSpring presenter can improve students' learning outcomes in English subjects because the developed media can be used as a communication tool to convey the material by the teacher(Pritakinanthi, 2017). ). The research by Ahmad Afandi states that ICT mathematics learning media using interactive Powerpoint and iSpring Presenter can increase teachers' knowledge and understanding in providing interactive learning so learning in the classroom is more enjoyable (Afandi, 2017). The research by Agna Deka Cahyanti states that the development of an evaluation tool with iSpring is worthy of being used as an evaluation tool for mathematics learning. (Cahyanti et al., 2019).

\section{CONCLUSION AND SUGGESTION}

Based on the results of the study, the interactive mathematics multimedia learning based on iSpring Presenter has met the requirements and is considered feasible to be used in the learning process as a supporting media for learning and able to increase students' interest in learning through varied learning activities. The use of the interactive mathematics multimedia learning based on iSpring Presenter succeeded in increasing students' learning interest proven by the $\mathrm{N}$-Gain value of 0.704 with a high category. It is suggested for further researchers to conduct research in a broader context by developing media in improving other variables of mathematics learning.

\section{REFERENCES}

Afandi, A. (2017). Media ICT pembelajaran matematika menggunakan power point interaktif dan iSpring Presenter. Abdimas : Jurnal Terapan, 2(0), 1-8.

Andari, T., \& Lusiana, R. (2014). Pengembangan Perangkat Pembelajaran Dengan Menggunakan Pendekatan Quantum Learning Berbasis Needs Assesment Pada Materi Ruang-n Euclides. Jurnal Ilmiah Pendidikan Matematika, 3(1), 1-10.

Aprilia, F. (2012). Faktor-faktor Yang Mempengaruhi Minat Berwirausaha Pada Siswa Kelas XII SMK Negeri 1 Kandeman Kabupaten Batang Tahun 2011/2012. Economic Education Analysis Journal, 1(2), 1-5.

Asmawati, R., \& Wuryanto. (2014). Keefektifan Model Pembelajaran LC 5E Dan TSTS Berbantuan LKPD Terhadap Hasil Belajar. Jurnal Kreano, 5(1), 26-32.

Azmidar, A., Darhim, D., \& Dahlan, J. A. (2017). Enhancing Students' Interest through 
Mathematics Learning. Journal of Physics: Conference Series, 895, 12072.

Cahyanti, A. D., Farida, F., \& Rakhmawati, R. (2019). Pengembangan Alat Evaluasi Berupa Tes Online/Offline Matematika dengan Ispring Suite 8. Indonesian Journal of Science and Mathematics Education, 2(3), 363-371.

Choirudin, C. (2017). Efektivitas Pembelajaran Berbasis Schoology. NUMERICAL: Jurnal Matematika Dan Pendidikan Matematika, 101-126.

Febriana, L. C., Sulur, \& Yudyanto. (2014). Pengembangan Lembar Kerja Siswa (LKS) Fisika Materi Tekanan Mencakup Ranah Kognitif, Afektif dan Psikomotor Sesuai Kurikulum 2013 untuk Siswa SMP/MTs. Jurnal Universitas Negeri Malang, 2(1), 1-12.

Fitri, A. (2011). Pengembangan Perangkat Pembelajaran Statistika Dasar Bermuatan Pendidikan Karakter Dengan Metode Problem Based Learning. Jurnal PP, 1(2), 159-165.

Fitri, H., \& Wardi, Y. (2026). Pengaruh Model Pembelajaran Type Two Stay Two Stray dan Minat Belajar terhadap Hasil Belajar Ekonomi pada Siswa kelas X SMA Dian Andalas Padang. Jurnal Ilmiah Mahasiswa (JIM) Pendidikan Fisika, 1(4).

Harsyad, F., Afif, A., \& Abrar, A. I. P. (2016). Studi Komparasi Penggunaan Ice Breaking Dan Brain Gym Terhadap Minat Belajar Matematika Siswa Kelas VII SMP Negeri 21 Makassar. Jurnal Matematika Dan Pembelajaran, 4(2), 184-197.

Hartono, W., \& Noto, M. S. (2017). Pengembangan Modul Berbasis Penemuan Terbimbing untuk Meningkatkan Kemampuan Matematis pada Perkuliahan Kalkulus Integral. Jurnal JNPM ( Jurnal Nasional Pendidikan Matematika ), 1(2), 320-333.

Himmah, F. (2017). Pengembangan Multimedia Interaktif Menggunakan Ispring Suite 8 Pada Sub Materi Zat Aditif Untuk Meningkatkan Hasil Belajar Siswa SMP Kelas VIII. Pendidikan Sains, 5(2).

Indraningtias, A., Diah, \& Ariyadi Wijaya. (2017). Pengembangan Perangkat Pembelajaran Berbasis Pendekatan Matematika Realistik Materi Bangun Ruang Sisi DatarBerorientasi Pada Kemampuan Berpikir Kritis Siswa Kelas VIIISMP. Jurnal Pendidikan Matematika, 6(5), 1-10.

Kinta Marini, C., \& Hamida, S. (2014). Pengaruh Self Efficacy , Lingkungan Keluarga, Dan Lingkungan Sekolah Terhadap Minat Berwirausaha Siswa SMK Jasa Boga. Jurnal Pendidikan Vokasi, 4(2), 195-207.

Melisa. (2016). Pengembangan Modul Berbasis Penemuan Terbimbing Yang Valid Pada Perkuliahan Kalkulus Peubah Banyak 1. LEMMA, 1(2), 21-27.

Munir. (2015). Multimedia Konsep \& Aplikasi dalam Pendidikan. Bandung: Alfabeta.

Nazir, M. (2010). Metode Penelitian. Bogor: Penerbit Ghalia Indonesia.

Nisak, K. (2013). Pengembangan Perangkat Pembelajaran IPA Terpadu Tipe Connected pada Materi Pokok Sistem Ekskresi kelas IX SMP. Jurnal Pendidikan Sains, 1(1), 81-84.

Nurwijayanti, A., Budiyono, \& Fitriana, L. (2019). Combining google sketchup and ispring 
suite 8: A breakthrough to develop geometry learning media. Journal on Mathematics Education, 10(1).

Pritakinanthi, A. S. (2017). Pengembangan Media Pembelajaran Menggunakan iSpring untuk Meningkatkan Hasil Belajar Mata Pelajaran Bahasa Inggris Kelas VIII SMP Negeri 37 Semarang. Universitas Negeri Semarang.

Rizkiah, A. W., Nasir, \& Komarudin. (2018). LKPD Discussion Activity Terintegrasi Keislaman dengan Pendekatan Pictorial Riddle pada Materi Pecahan. Desimal : Jurnal Matematika, 1(1), 39-47.

Rudiono, T., Dafik, \& Wahyuningrum, E. (2015). Pengembangan Perangkat Pembelajaran Berbasis Rme Berorientasi Terciptanya Berfikir Tingkat Tinggi Materi Perbandingan Kelas VII. Pancaran, 4(1), 45-54.

Sari, A. U., Farida, \& Putra, F. G. (2017). Pengembangan Media Pembelajaran Berbantuan Web Dengan Pendekatan Etnomatematika Pada Pokok Bahasan Bangun Ruang Sisi Datar. In Prosiding Seminar Nasional Matematika dan Pendidikan Matematika (pp. 209-214). Lampung.

Sari, F. K., Farida, \& Syazali, M. (2016). Pengembangan Media Pembelajaran (Modul) berbantuan Geogebra Pokok Bahasan Turunan. Al-Jabar: Jurnal Pendidikan Matematika, $7(2), 135-151$.

Sastrakusumah, E. . (2018). Pengaruh Media Pembelajaran Interaktif Berbantuan Aplikasi Ispring Presenter Terhadap Kemampuan. Teknologi Pembelajaran, 3(1).

Siagian, R.E.F. (2015). Pengaruh Minat dan Kebiasaan Belajar Siswa Terrhadap Prestasi Belajar Matematika. Formatif: Jurnal Ilmiah Pendidikan MIPA, 2(2).

Subandi, S., Choirudin, C., Mahmudi, M., Nizaruddin, N., \& Hermanita, H. (2018). Building Interactive Communication with Google Classroom. International Journal of Engineering \& Technology, 7(2.13), 460-463.

Sugiyono. (2011). Statistik untuk Penelitian. Bandung: Alfabeta.

Sugiyono. (2015). Metode Penelitian Kombinasi (Mixed Methods). Bandung: Alfabeta.

Sulistyowati, Y., \& Sugiman. (2014). Pengembangan Perangkat Pembelajaran Bangun Ruang di SMP dengan Pendekatan Creative Problem Solving. Phytagoras, 9(2), 219-232.

Supiyati, \& Jailani. (2014). Pengembangan Perangkat Pembelajaran Bangun Ruang SMP dengan Pendekatan SAVI ( Somatik, Auditori, Visual, Intelektual). Jurnal Pendidikan Matematika, 9(2), 175-185.

Supriadi, N., Farida, \& Lestari, B. D. (2018). Pengembangan Modul Kalkulus Pada Materi Turunan Bernuansa Keislaman dengan Pendekatan Penemuan Terbimbing. In YSSTEE International Conference (pp. 1-11).

Susanti, Musdi, E., \& Syarifuddin, H. (2017). Pengembangan Perangkat Pembelajaran Matematika Materi Statistik Berbasis Penemuan Terbimbing Untuk Meningkatkan Kemampuan Pemecahan Masalah Matematis Materi Statistika. Jurnal JNPM ( Jurnal 
Nasional Pendidikan Matematika ), 1(2), 305-319.

Vikulova, L. ., Makarova, I., \& Gerasimova, S. . (2018). Features of iSpring suite learningplatform for teaching foreignlanguages. Revista ESPACIOS, 39(2).

Wagino, N. ., \& Zaenuddin. (2015). Pembuatan Media Pembelajaran Interaktif Dengan Perangkat Lunak Ispring Presenter Di Sman 4 Banjarmasin. Al-Ikhlas Jurnal Pengabdian, 1(1).

Wijayanti, S., \& Sungkono, J. (2017). Pengembangan Perangkat Pembelajaran mengacu Model Creative Problem Solving berbasis Somatic, Auditory, Visualization, Intellectually. AlJabar: Jurnal Pendidikan Matematika, 8(2), 101-110.

Yeh, C. Y. C., Cheng, H. N. H., Chen, Z.-H., Liao, C. C. Y., \& Chan, T.-W. (2019). Enhancing achievement and interest in mathematics learning through Math-Island. Research and Practice in Technology Enhanced Learning, 14(1).

Yusnita, R., \& Subanti, S. (2014). Pengembangan Perangkat Pembelajaran Berbasis Penemuan Terbimbing (Guided Discovery) Dengan Pendekatan Somatic, Auditory, Visual, Intellectual (SAVI) Pada Materi Pokok Peluang Kelas IX SMP Tahun Pelajaran 2013/2014. Jurnal Elektronik Pembelajaran Matematika, 2(4), 379-388. 